UDC 339

DOI: 10.31651/2076-5843-2019-3-12-20

\section{SHPILEVA Vira}

Doctor of Economics, Professor,

Department of Economics, Finance, Accounting and

Auditing,

Cherkasy branch of Private Higher Educational

Establishment «European University»,

Cherkasy, Ukraine

ORCID ID: https://orcid.org/0000-0002-3891-3804

vera_bsh.21@ukr.net

\section{TENG Serhii}

Graduate student,

Private Higher Educational Establishment

«European University»,

Kyiv, Ukraine

ORCID ID: https://orcid.org/0000-0003-0320-4386

fimyar@ukr.net

\title{
LOGISTICS AS A STRATEGY OF INCREASING COMPETITIVENESS IN INTERNATIONAL MARKETS
}

The research revealed factors of increasing the efficiency of enterprise's logistic activity in a dynamic market environment, which can create competitive advantages related to logistics processes, due to changes in the priorities of value chain formation and, accordingly, the emergence of new opportunities for logistical support of production processes. Indicators of logistic service quality for individual elements of the logistic process have been systematized, a model of optimization of logistic processes by improving the quality of customer service has been developed. It is established that the competitiveness of the enterprise is based on quality logistic service, which is built not on getting new customers, but on increasing the offered values to existing consumers. Therefore, the main goal in this case is to fully meet the needs of the consumer, which is advisable to implement through the development of logistics processes that facilitate maintenance at lower costs. It is established that the goal of logistics solutions in global logistics is to optimize material, information and financial flows in the enterprise by ensuring efficient management of production, transport, communications with logistics centers, customs, the use of information support systems and advanced storage technologies. The main purpose of the logistics strategy in foreign economic activity is to support the overall corporate strategy. Logistics strategies at the international level include the cost minimization strategy, the minimization of investments in our own infrastructure, and the refinement of customer service strategies.

Keywords: logistics; international competitiveness; factors of logistic services efficiency; quality of logistics services; logistics solutions; optimization of logistics processes; logistic strategies; barriers to the development of international logistics.

Introduction. Modern business activities characterized by complexity and dynamism, this determines the cause to make rational logistics management, which will solve many problems associated with the study of the structure of relationships between elements of the company, its relationship with the environment, optimal modes of elements operation entire within the material and functional content of relevant activities.

Hard competition encourages enterprises to find new reserves of competitiveness, which had not previously been considered as a source of strengthening their competitive position in the market. Among the latter, an increasingly important role is played by logistics.

Literature review. Logistics as a strategy of increasing competitiveness in international markets have been investigated by such scholars as A. Hadjinsky [1], D.Y. Bowersox [4], D. Kisperska-Moroń and St. Krzyzoniak [5] and other. 
Purpose. The purpose of the article is to study logistics from the point of view of strategic ensuring of the competitiveness of enterprises in international markets.

Results and discussion. The logistics concept includes significant reserves to save time and optimize the costs of the implementation of logistics operations. Studies conducted by the National Council of Physical Distribution Management, USA, have shown that the introduction of an integrated logistics system could lead to savings of $10-20 \%$ of total corporate spending [1].

At the same time, logistics is still a new scientific direction, which is in its formative stages and requires more detailed study, not only as a separate system, but also an integral part of the enterprise operation mechanism. That is why it is important to explore the impact of logistics on the operations and competitiveness of small-scale wholesale trade enterprises.

Experience of leading countries of the world proves the high efficiency of the logistics in obtaining sustainable competitive advantages. Due to the logistics companies provide the required level of end-user services, providing him with a certain added value. Additional values can touch and elasticity largest party supply, and elasticity and flexibility of payment conditions on the timing and place of execution of the order.

By linking the foregoing with the logistics concepts characteristics dwell in detail the nature of the most important components of the logistics competitiveness of enterprises, among which are the following:

- elimination the logistics operations time;

- improving the quality of services;

- reducing the logistics cost.

Justification of the choice of these factors is shown in Table 1.

Table 1

The benefits of choosing the main logistic factors

\begin{tabular}{|l|c|c|c|}
\hline $\begin{array}{c}\text { Components of } \\
\text { enterprise } \\
\text { competitiveness }\end{array}$ & Time & Quality of service & Logistical costs \\
\hline Production potential & $\begin{array}{c}\text { Eliminating time using } \\
\text { operations, effective } \\
\text { organization of the } \\
\text { production process }\end{array}$ & $\begin{array}{c}\text { Stable party product } \\
\text { delivery, no downtime }\end{array}$ & $\begin{array}{c}\text { Effective planning of } \\
\text { production costs }\end{array}$ \\
\hline Marketing & $\begin{array}{c}\text { Coordinated marketing } \\
\text { services, established } \\
\text { cooperation with } \\
\text { suppliers, short terms of } \\
\text { order execution }\end{array}$ & $\begin{array}{c}\text { High sales volumes, } \\
\text { continued commitment to } \\
\text { consumers and after-sales }\end{array}$ & $\begin{array}{c}\text { High maintenance } \\
\text { costs lead to lower } \\
\text { overall costs in the } \\
\text { enterprise }\end{array}$ \\
\hline Finance & $\begin{array}{c}\text { Reduction of operation } \\
\text { costs }\end{array}$ & $\begin{array}{c}\text { Increasing volumes of } \\
\text { financial flows as a result } \\
\text { of higher sales volumes }\end{array}$ & $\begin{array}{c}\text { Budgeting for decline } \\
\text { in expenses due to a } \\
\text { reduction costs for } \\
\text { warehousing and } \\
\text { storage }\end{array}$ \\
\hline
\end{tabular}

Source: compiled by the author [2], [3].

Optimization of production time due to logistics analysis of the process significantly affects the final price of the product. The same product can be made now at various ways of organizing its activities. As noted D. Bowersox, «logistics system causes the goods to pass a series of successive steps, which give it the value, resulting in a product gets to the right place at the right time in the appropriate amount and form» [4].

According to the logistic concept, adding the cost of goods takes place in the process of changing the useful parameters of time, space and form. Thus, the value of the goods is formed throughout the chain, but thanks to the logistics companies provide the necessary level of customer service by providing some additional value, except for those who provide the production process. Model the impact of the time factor in the competitiveness of enterprises is shown in Fig. 1. 


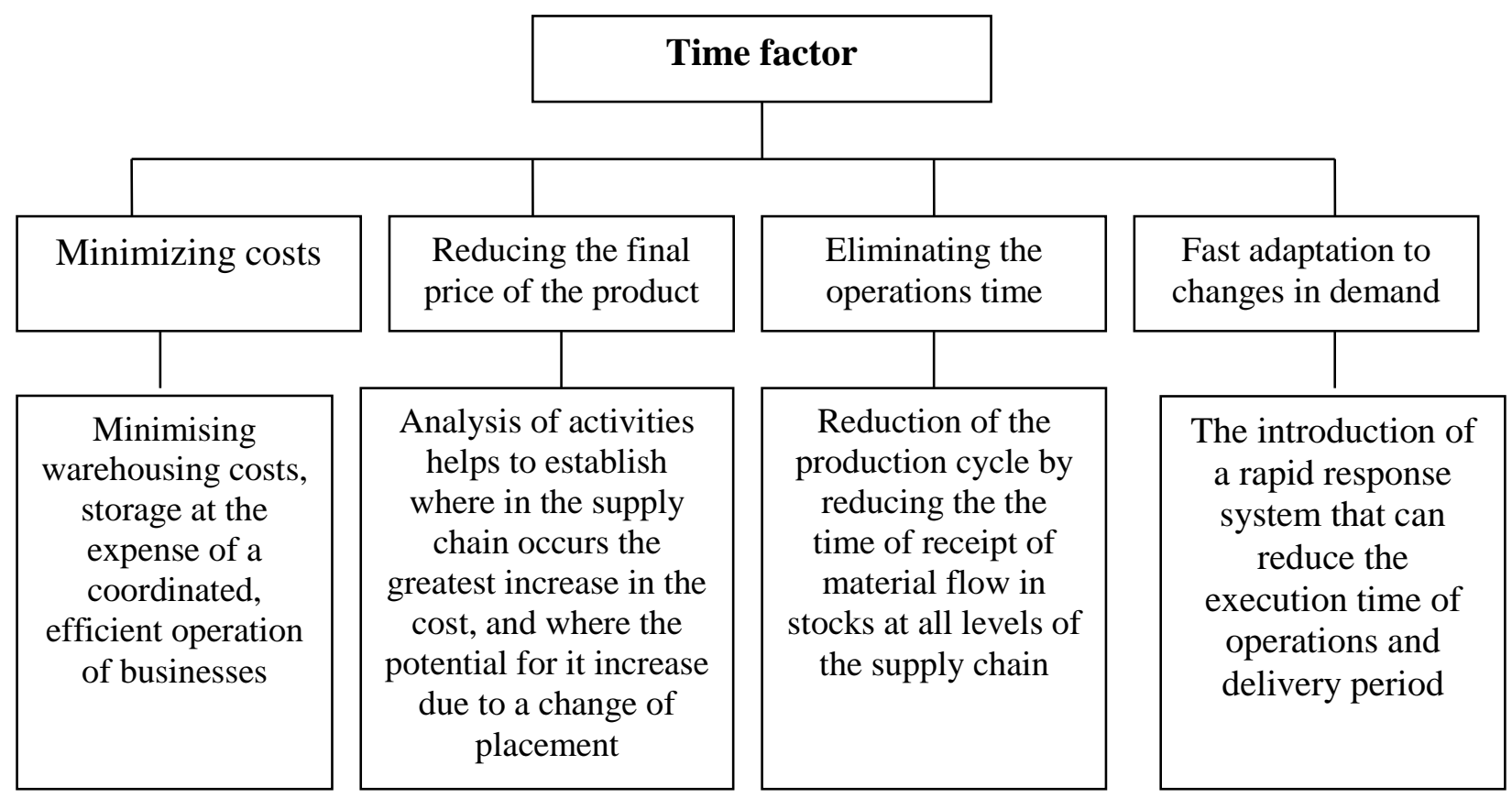

Fig. 1. The impact of the time factor in the competitiveness of enterprises

Source: compiled by the author [3], [5].

Adopted today logistical ideology of «customer focused manufacturing» [6] in the first place makes demands of flexibility production and the use of feedback between stages of product distribution. In accordance with these requirements, the adaptation to the consumers interests requires of companies producing not just a product of adaptation to specific customer needs but support ongoing feedback from them and adapt the entire circuit to such needs. The result of the implementation of these conditions is to improve the quality of service and, above all, the reduction of lead times and compliance with the agreed delivery schedule.

Thus, the time factor, along with the price and quality of the product determines the success of the enterprise functioning on the market, and the expectancy of the logistics cycle, as it is a special case, together with indicators of logistics cost, service level, security of supply is used as a criterion the efficiency of logistics management in the enterprise.

The competitiveness of the enterprise, based on a quality logistics service, not based on getting new customers but in increasing the proposed value of existing customers. Therefore, the main purpose in this case is the full satisfaction. The increase in cost for the consumer can occur through the development of logistics processes to facilitate maintenance at a lower cost, which aim to improve the quality and utility.

Enlarge utility service can be by express delivery, shorter terms of order fulfillment, flexible response to changes in the market environment. Also, using logistics processescan be reduced the cost of creating these utilities due to lower inventories, lower costs for the order or reduce losses from inventory shortages.

Quality customer service involves taking into account individual needs of clients. A list of criteria standards and service levels shown in Table 2.

Reducing the time of order realization depends on three factors: processes, information and decision-making. The cycle of implementation of the order, which covers the following elements: preparation of orders, processing, dispatch of the goods ordered, indicating the possibility of accelerating the individual logistics activities and processes in the future. 
The elements and indicators (standards) of consumer services

\begin{tabular}{|c|c|c|}
\hline Elements of service & Short description & $\begin{array}{l}\text { Typical indicators } \\
\text { (standards) }\end{array}$ \\
\hline Product availability & $\begin{array}{l}\text { Expresses the presence of reserves (according to the } \\
\text { level of demand), the basic units of goods }\end{array}$ & $\begin{array}{l}\% \text { availability of basic } \\
\text { units of goods }\end{array}$ \\
\hline Lead time & $\begin{array}{l}\text { The time from application to receipt of the goods. It } \\
\text { is measured in units of time and a deviation from the } \\
\text { standard or planned cycle time }\end{array}$ & Speed and consistency \\
\hline $\begin{array}{l}\text { The flexibility of the } \\
\text { distribution system }\end{array}$ & $\begin{array}{l}\text { The system's ability to respond to specific or } \\
\text { unexpected customer needs }\end{array}$ & $\begin{array}{l}\text { The response time for } \\
\text { special orders }\end{array}$ \\
\hline $\begin{array}{l}\text { Information support of } \\
\text { the distribution system }\end{array}$ & $\begin{array}{l}\text { The ability of the enterprise information system to } \\
\text { respond accurately and promptly to customer needs }\end{array}$ & $\begin{array}{c}\text { Speed, accuracy and } \\
\text { detail of communication }\end{array}$ \\
\hline $\begin{array}{l}\text { Liquidation of errors } \\
\text { and shortcomings in } \\
\text { the system of } \\
\text { distribution }\end{array}$ & $\begin{array}{l}\text { The effectiveness of the procedures and the time } \\
\text { required to restore the functioning of the distribution } \\
\text { system }\end{array}$ & $\begin{array}{l}\text { The response time to } \\
\text { eliminate errors }\end{array}$ \\
\hline After-sales service & Efficiency of service after delivery & $\begin{array}{l}\text { Time and quality of } \\
\text { response to the problem }\end{array}$ \\
\hline
\end{tabular}

Source: compiled by the author.

Values for the adoption of logistics solutions and new concepts are distributed between the producers and their customers as follows (Fig. 2)

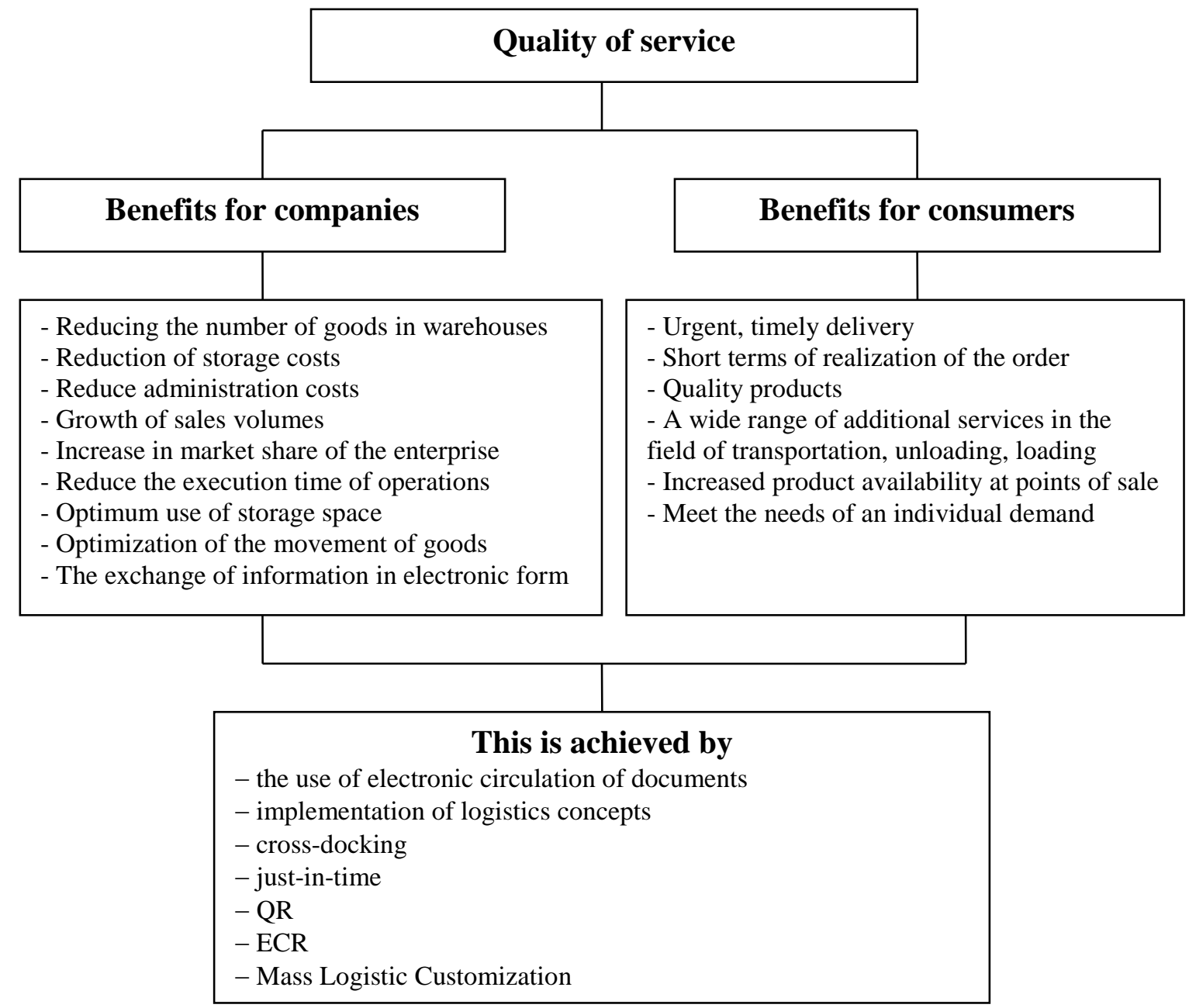

Fig. 2. Optimization of logistic processes by improving customer service quality Source: compiled by the author. 
For consumers, the value of an economic nature come out on top. For example, thanks to the introduction ECR strategy reduces the amount of goods in warehouses and, accordingly, warehousing costs, and administrative costs. The implementation strategy also affects the growth of sales and therefore market share of the enterprise. Through the introduction of a rapid response system is reducing the time of operations and delivery period.

Changing the conditions of competition, the growth of consumer requirements for quality of life and, consequently, consumer properties of household goods, computerization of production processes, quality control - all of these requirements necessitate solutions businesses effectively the problem of production cost management. The main advantage of logistics costs control as a means of increasing the efficiency of production is the production of competitive products due to lower costs and, accordingly, reduced the unit price of products; quality and availability of real information about the logistics costs of certain products; providing objective data to make informed and effective management decisions.

Thus, a special place in ensuring the company's competitiveness in a dynamic market environment may take the competitive advantages associated with logistics activities, due to changes in the priorities of the formation of value chains and, consequently, the emergence of new opportunities logistics competitiveness.

Business is increasingly conscious of the logistics strategic importance, primarily due to significant potential savings. Modern accounting information system of transportation, storage technologies guarantee cargo safety and timely delivery, energetic and professional staff are major factors in the success of the company, which focuses on logistics principles.

The purpose of logistics solutions in global logistics is to optimize movement of material information and financial flows in the enterprise by ensuring efficient management of production, transport, relationships with logistics centers, customs, use of information decision support systems and advanced storage technologies (Fig. 3).

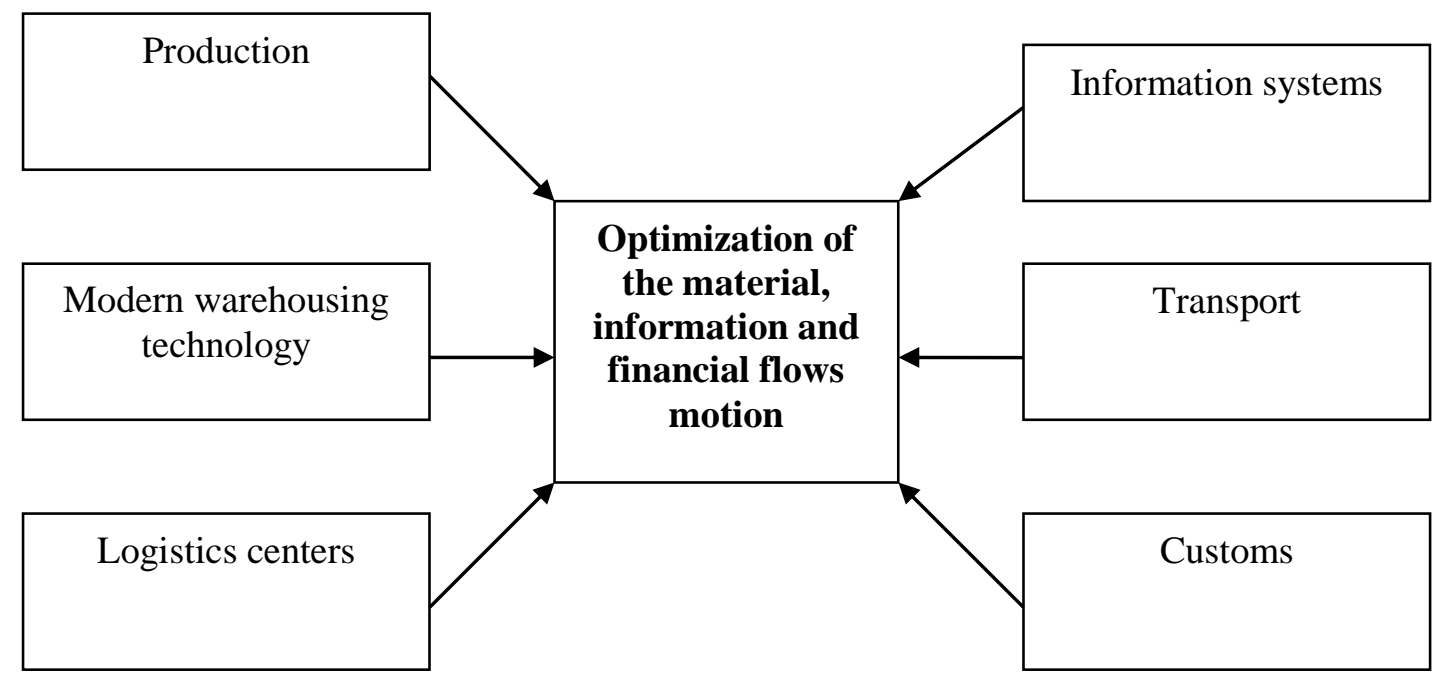

Fig. 3. The purpose of logistics solutions in global logistics

Source: compiled by the author [6].

Logistics related to the promotion of products on the market. Therefore, the strategy of market logistics positioning should take into account the different reactions of logistic process participants at the national and international levels for the proposed prices, tariffs and quality of logistics services. The company that wants to keep demand for their products at the same level or increase it, should know the current and future behaviour of the logistics process and, therefore, to consider:

- their own possible participation in the competition, the possibility of existing channels of supply, continuity and flexibility of their work in the international trade;

- the marketing specifics (advertising, sales promotion, market research), its effectiveness to control the behaviour of buyers and increase its own market share. 
Key tasks and foundations of strategic logistics management associated with the inclusion the logistics in the structure of the strategic planning of the company. That stems from the role of logistics as an advanced cost analysis tool, logistics and strategy formation to determine its place in the overall business strategy.

The strategic planning process of building the global logistics systems in foreign economic activities shall consist of the following stages: assessment, setting objectives, setting priorities and implementation (Fig. 4).

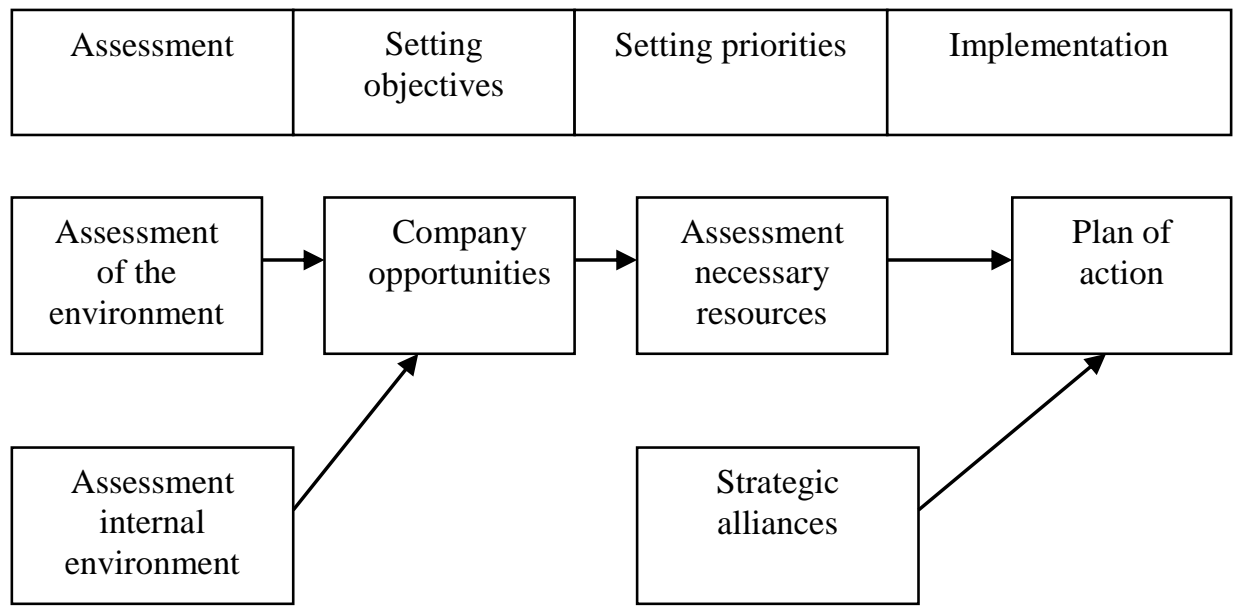

Fig. 4. Stages of strategic planning the global logistics systems

Source: compiled by the author.

The experience of leading countries shows that logistics play an important role in forming the overall corporate strategy. This is especially true of companies that practice the most advanced technology based on integrated logistics networks. The introduction of modern methods of logistics management in business practices, and including at the international level can reduce inventory, lower costs of production and circulation, compress time limits functional logistics cycles, improve customer service. The main purpose of logistics strategy in foreign economic activity - to support overall corporate strategy. Among logistics strategies at the international level can be noted the minimize costs strategy, minimize investment in its own infrastructure, dramatically improving customer service strategies.

International logistics strategy must conform a corporate strategy based on their own development strategies. For example, if the company is developing a strategy of growth through access to international markets, the logistics strategy can be minimizing their own investments in logistics infrastructure by attracting logistics and transport providers of logistics operations. If elected strategy to minimize commodity price, the accompanying logistics strategy can be the maximum reduction of logistics costs. The company can make strategic decisions aimed at minimizing overall costs, improve service levels, maximize profits, the full utilization of competitive advantages, reduce the assets.

Defining strategies in the construction and operation of global logistics systems is fundamental to the overall success. Even if the company does not intend to build its core competitive advantages in logistics competence, it must equally develop logistics capabilities as part of the creation of use value. Strategic goals are achieved in logistics due to the establishment of the basic principles of corporate governance. This requires:

- to establish a link between logistics and overall corporate strategy;

- make full use of all the information is available;

- to mobilize staff members to achieve the set objectives;

- to identify partnerships (with transport, storage and other companies) that are necessary for solving tasks;

- to determine the budget needed for the implementation of goals;

- to determine the optimal level of customer service; 
- to keep flexibility in carrying out its operations [7].

Ways of implementing international logistics strategies are summarized in Table 3.

Table 3

Ways of implementing international logistics strategies

\begin{tabular}{|c|c|c|}
\hline Technique & Essence of the technique & Result \\
\hline $\begin{array}{l}\text { 1. The use of } \\
\text { specialized } \\
\text { organizations }\end{array}$ & $\begin{array}{l}\text { Tool to limit the range and mix of goods } \\
\text { (including goods, their range and their } \\
\text { associated parameters) produced in one place }\end{array}$ & $\begin{array}{l}\text { The company receives savings } \\
\text { through increased scale of } \\
\text { production }\end{array}$ \\
\hline $\begin{array}{l}\text { 2. Centralization of } \\
\text { stocks }\end{array}$ & $\begin{array}{l}\text { Needs arising from the onset of the era of } \\
\text { globalization. Companies strive not only to a } \\
\text { more rational distribution of its production on } \\
\text { fewer companies, but also to the consolidation } \\
\text { reserves and their concentration on a smaller } \\
\text { number of locations in order to reduce reserve } \\
\text { requirements. }\end{array}$ & $\begin{array}{l}\text { Many enterprises deliberately } \\
\text { close their stores and convert } \\
\text { them into regional distribution } \\
\text { centers that serve large areas }\end{array}$ \\
\hline $\begin{array}{l}\text { 3. Deferral and } \\
\text { localization }\end{array}$ & $\begin{array}{l}\text { Way to transfer the final product finishing and } \\
\text { individualisation generated from standard } \\
\text { components and assembly modules, until the } \\
\text { entry into the market }\end{array}$ & $\begin{array}{l}\text { At the the final design takes into } \\
\text { account the specific needs of } \\
\text { customers }\end{array}$ \\
\hline
\end{tabular}

Source: compiled by the author [7], [8].

In a global world, there are many options for the conduct of international trade: from the traditional focus on export-import operations to implement the concept of "enterprise without citizenship". In other words, does not exist the universal model of international logistics operations management and there can not be, every enterprise has to find their own solutions. So it is appropriate to summarize the experience of the most successful organizations by the following models:

- Sales of finished products are carried out around the world, while providing logistics and production is concentrated in a single center (mainly in the home country);

- The production is organized in one center (usually at home), but the supply of raw materials, semi-finished products and components are carried out from many countries;

- The economic entity is registered and operates as a national company, which is a significant proportion of the procurement of basic materials in local markets;

- A network of fully independent organizations that supply from the local markets and delivering there finished products.

Globalization of the world economy required to ensure proper logistics management. Companies from different countries come to the world market, motivated by the desire to market growth. Expanding international trade is necessary to the relevant logistics service.

Thanks to the development of international economic relations are eliminated border economic activities of companies, but to the development of international logistics are still serious barriers - plenty of trade, financial, customs and other limitations due to differences in political systems, economic and social levels of development of countries, the difference in standard of living their population, etc. In addition, the international logistics necessary to consider the competition, restrictions on distribyutivnye network of transnational corporations, etc. Management in an international logistics system must take into account the factors that are important for the successful promotion of international logistics.

Figure 5 shows the barriers in the development of international logistics, affecting the global logistics management. As seen in Figure 5, the barriers in the development of international logistics are divided into three groups: 1) market and competitive barriers; 2) financial barriers; 3 ) barriers in distribution. Interstate specifics of distribution channels hinders the development of international logistics. It is necessary to overcome standardization problems caused by national and regional features of transport means, infrastructure, railways, cargo handling equipment. In this direction 
works the International Organization for Standardization (ISO) which has reached certain success in unification and standardization of transport equipment.

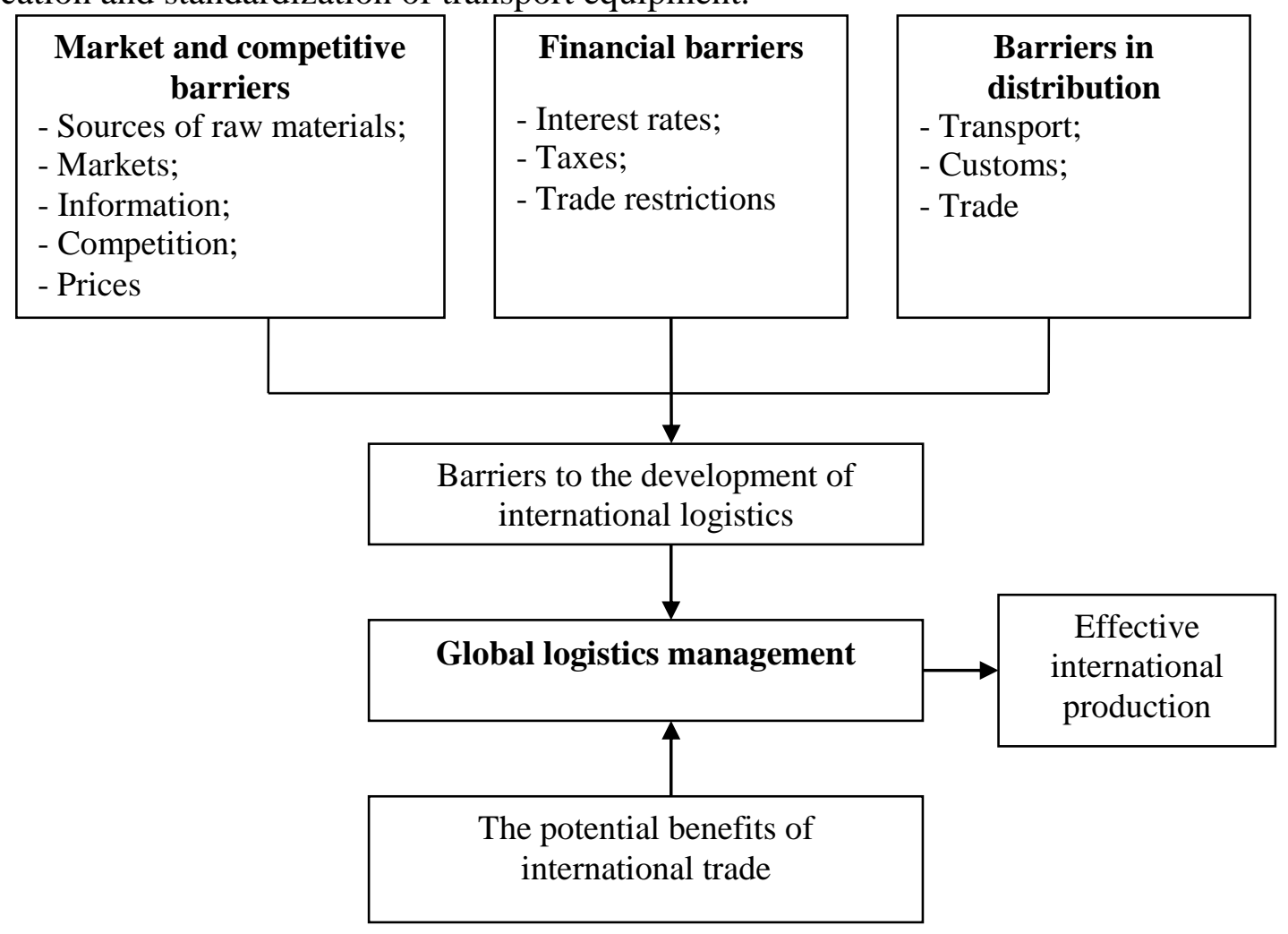

\section{Fig. 5. Barriers in the development of international logistics, affecting the global logistics management}

Source: compiled by the author [9], [10].

The decision on the choice of organization distribution channel take in view of trade barriers regulations directly restrict the type of goods or increase the level of customs duties in the case of excess imports.

Conclusions. With the development of global market its participants carefully weighed the factors «for» and "against», considering the logistics on a global scale, in terms of global categories. First of all, assess existing barriers (obstacles) and alternative solutions to problems in the event of force majeure situations. Both the domestic and international markets is subject to the same principles of logistics. However, in the second operating environment is much more complex and involve greater costs.

\section{References}

1. Measuring productivity in physical distribution, Chicago, IL: NCPDM. Retrieved from: https://www.worldcat.org/title/measuring-productivity-in-physical-distribution-a-40-billion-dollargoldmine/oclc/6448457?referer=br\&ht=edition (Accessed 17 May 2019).

2. Kanke, A.A. (2016). Logistics. Moscow: Forum (in Russ.)

3. Melnikov, V.P. (2014). Logistics. Moscow: Yuryt (in Russ.)

4. Bowersox, Donald J. (2014). Logistics: Integrated Supply Chain. Moscow: Olimp-Business (in Russ.)

5. Margunova, V.I. (2013). Logistics. Minsk: Higher School (in Russ.)

6. Hadjinsky, AM. (2013). Logistics. Moscow: Publishing and Trading Corporation «Dashkov and $\mathrm{K}^{\circ} \gg$ (in Russ.)

7. Coyle, J. (2012). Logistic management. Warsaw: PWE (in Pol.)

8. Murphy, P. (2011). Contemporary Logistics. Harlow: Prentice Hall (in Eng.)

9. Kisperska-Moroń, D., Krzyzoniak, St. (2009). Logistics. Poznan (in Pol.)

10.Rajmund, K. Szulc. (2016) Services without borders. Review of Economic Legislation, 4, 26-34. 


\section{ШПИЛЬОВА Віра Олексіївна}

д.е.н., професор, завідувач кафедри економіки, фінансів, обліку і аудиту,

ЧФ ПВНЗ «Свропейський університет», м. Черкаси, Україна

\section{ТЕНГ Сергій Андрійович}

аспірант,

ПВНЗ «Свропейський університет»,

м. Київ, Україна

\section{ЛОГІСТИКА ЯК СТРАТЕГІЧНИЙ НАПРЯМ ПІДВИЩЕННЯ КОНКУРЕНТОСПРОМОЖНОСТІ НА МІЖНАРОДНИХ РИНКАХ}

Проблема. Сучасна господарська діяльність підприємств характеризується складністю та динамізмом, ие зумовлює необхідність здійснення раиіонального логістичного управління, здатного вирішити багато проблем, пов'язаних з удосконаленням структури взаємозв'язків між структурними підрозділами компаній, ї̈ взаємодії з навколишнім середовищем в межах матеріального та функиіонального змісту відповідної діяльності. Жорстка конкурениія спонукає підприсмства до пошуку нових резервів конкурентоспроможності, які раніше не розглядалися як джерело зміцнення їх конкурентних позицій на ринку. Серед них все більшу роль відіграє логістика.

Метою наукової статті є дослідження логістики з позицій стратегічного забезпечення підвищення конкурентоспроможності підприємств на міжнародних ринках.

Результати. У межах проведеного дослідження виявлені фактори підвищення ефективності логістичної діяльності підприємств в динамічному ринковому середовищі, які можуть створити конкурентні переваги, пов'язані з логістичними процесами, що обумовлено змінами в пріоритетах формування ланцюгів вартості $i$, відповідно, появою нових можливостей логістичного забезпечення виробничих процесів. Систематизовані індикатори якості логістичного обслуговування для окремих елементів логістичного прочесу, розроблена модель оптимізації логістичних процесів шляхом покращення якості обслуговування споживачів. Встановлено, що конкурентоспроможність підприсмства заснована на якісному логістичному обслуговуванні, що будується не на отриманні нових споживачів, а на збільшенні пропонованих иінностей існуючим споживачам. Тому головною метою в такому випадку, є повне задоволення потреб споживача, яке доиільно здійснювати через розвиток логістичних процесів, щзо полегшують обслуговування при більш низьких витратах. 3'ясовано, що метою логістичних рімень у глобальній логістиці є оптимізація руху матеріальних інформачійних та фінансових потоків на підприємстві шляхом забезпечення ефективного управління виробництвом, транспортом, зв'язками з логістичними центрами, митницею, використання систем підтримки інформачійних рімень та передових технологій зберігання. Основне призначення логістичної стратегії у зовнішньоекономічній діяльності - підтримка загальної корпоративної cmpameziï.

Наукова новизна. Дістало поальшого розвитку стратегічне планування побудови глобальних логістичних систем у зовнішньоекономічній діяльності, зокрема, доведено, що процес такого планування повинен складатися з таких етапів: оиінка, встановлення иілей, встановлення пріоритетів та впровадження. Виявлені шляхи реалізачії міжнародних логістичних стратегій та бар'єри в розвитку міжнародної логістики, щяо впливають на глобальне управління логістикою.

Висновки. За підсумками дослідження зроблено висновок, що з розвитком глобального ринку його учасникам необхідно більш ретельно зважували позитивні та негативні фактори, здійснюючи логістичну діяльність на міжнародних ринках, зокрема з точки зору глобальних категорій. Перш за все, доцільно оцінювати існуючі бар'єри (перешкоди) та альтернативні варіанти вирішення проблем у випадку непередбачених ситуачій. Як внутрішній, так $і$ міжнародний ринки підпорядковуються однаковим принципам логістики, однак робоче середовище міжнародного ринку набагато складніше і вимагає більших витрат.

Ключові слова: логістика; міжнародна конкурентоспроможність; фактори ефективності логістичних послуг; якість логістичного обслуговування; логістичні рімення; оптимізація логістичних прочесів; логістичні стратегії; бар'єри в розвитку міжнародної логістики. 